\section{Paulina Chojnacka}

Katolicki Uniwersytet Lubelski Jana Pawła II paulina.chojnacka14@wp.pl

ORCID: 0000-0001-5360-739X

\section{Marcin Jan Janecki}

Katolicki Uniwersytet Lubelski Jana Pawła II/

/Universidad de Salamanca

janekkarmel@gmail.com

ORCID: 0000-0003-4376-6535

\section{Biblica}

et

Patristica

Thoruniensia

12 (2019) 3: 305-330

ISSN (print) 1689-5150

ISSN (online) 2450-7059

\title{
De Verbo Dei Hugona ze św. Wiktora. Wprowadzenie i przekład
}

\section{Hugh of Saint-Victor's De Verbo Dei. Introduction and first Polish translation}

\begin{abstract}
Streszczenie. Niniejszy artykuł zawiera pierwszy przekład na język polski opusculum Hugona ze św. Wiktora (zm. 1141) pt. De Verbo Dei, które stanowi cenny przykład średniowiecznej alegorycznej i tropologicznej metody interpretacji Biblii. Egzegeza Hbr 4,12-5,2, korzystająca z zasobów klasycznej sztuki retorycznej, pozwoliła Hugonowi na rozwinięcie takich filozoficznych i teologicznych wątków, jak: jedność Słowa Bożego, własna wizja antropologiczna, ludzkie możliwości poznawcze i wiedza Boga. Refleksja teologiczna dotyka także takich tematów, jak dialog, rozgrywający się między Bogiem a człowiekiem w świetle Hugonowej doktryny o naturze i łasce, kapłaństwo Chrystusa oraz obowiązki kapłanów i przełożonych w Kościele. Prócz wątków doktrynalnych przeanalizowano również środki językowe, służące wyrażeniu zamierzonych treści.
\end{abstract}

\begin{abstract}
The authors present the first Polish translation of the opusculum entitled De Verbo Dei, written by Hugh of St Victor (d. 1141). The writing is a valuable example of the medieval allegorical and tropological interpretation of the Bible. The exegesis of the Heb 4:12-5:2 gives rise to consideration of theological and philosophical topics such as unity of God's Word, Hugh's anthropology, human cognitive abilities and God's knowledge. Hugh's theological reflection embraces also issues such as the dialogue between God and man in the light of the doctrine of natura - gratia, Christ's priesthood and duties of the prefecti Dei in the Church. The analysis of the treatise pertains also to Hugh's language and its stylistic values.
\end{abstract}

Słowa kluczowe: Hugon ze św. Wiktora; egzegeza średniowieczna; teologia wiktorynów; komentarz do Hbr 4,12-5,2; analiza stylistyczna.

Keywords: Hugh of St.-Victor; medieval exegesis; Victorine theology; commentary on Heb 4:12-5:2; stylistic analysis. 


\section{Wstęp}

Badania nad teologiczną i filozoficzną myślą wieków średnich przekonują

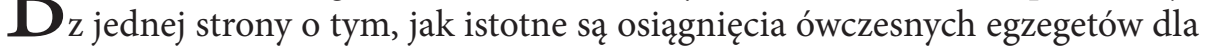
teologii współczesnej ${ }^{1}$, z drugiej zaś, jak wiele źródeł pochodzących z tej epoki czeka jeszcze na odkrycie ${ }^{2}$. Historia średniowiecznej egzegezy to historia tysiącletnia, z konieczności więc jej postać ulegała istotnym zmianom. Jak podkreślił P. Roszak, badając metodę egzegetyczną św. Tomasza z Akwinu, ważny przełom dokonał się w wieku XII'3 ; swój ważny wkład w dzieje interpretacji słów natchnionych mieli również wiktoryni.

Hugon ze św. Wiktora jest autorem, który wywarł ogromny wpływ na duchową kulturę Europy. Jego osoba i twórczość stają się przedmiotem coraz większego zainteresowania uczonych ${ }^{4}$. Napawa radością fakt, że również w Polsce myśl Hugona inspiruje coraz szersze grono badaczy5. Jednakże bogactwo jego spuścizny literackiej wciąż pozostaje w znacznym stopniu nieodkryte. Brakuje także przekładów na język polski jego utworów ${ }^{6}$. Aby zatem głębia myśli wiktoryna mogła inspirować szerszy krąg odbiorców, proponujemy przekład

1 Por. P. Roszak, Credibilidad e identidad. En torno a la Teología de la Fe en Santo Tomás de Aquino, Pamplona 2014, gdzie Autor podejmując filozoficzno-teologiczną dyskusję ze współczesnymi nurtami myślowymi, eksponuje walory rozwiązań Akwinaty.

2 Zob. S. Swieżawski, Dzieje europejskiej filozofii klasycznej, Warszawa-Wrocław 2000, s. 401.

3 P. Roszak, Between Dialectics and Metaphor, s. 507-508.

4 Za przykład mogą służyć prace prowadzone m. in. w Hugo von Sankt Viktor-Institut we Frankfurcie. G.A. Zinn nie waha się nazwać ostatnich lat renesansem w badaniach nad wiktorynami, zob. G.A. Zinn, Preface, w: Interpretation of Scripture, F. T. Harkins, F. van Liere (red.), s. 9.

5 Por. choćby: J. Soszyński, Wstęp, w: Hugon ze Świętego Wiktora, Didascalicon, czyli co i jak czytać, Warszawa 2017, s. 9-44; R. Tichy, Hugon ze Św. Wiktora, w: M. Frankowska-Terlecka (red.), Wszystko to ze zdziwienia, Warszawa 2006, s. 269-278; M. J. Janecki, Omnia disce. Mistrza Hugona ze św. Wiktora rady dla studentów, Studia Antyczne i Mediewistyczne 15 [50] (2017), s. 159-166; W. Bajor, „Zbawcze piękno” w teorii estetycznej wiktorynów, Roczniki Kulturoznawcze 3 (2012) s. 67-81; M. Zembrzuski, „O miłości! Cóż mogę o tobie powiedzieć?” Hugona ze św. Wiktora pochwała miłości, Studia Theologica Varsaviensia 1 (2017), s. 159-180.

6 Ostatnie polskie przekłady: Hugon ze Świętego Wiktora, Didascalicon, czyli co i jak czytać, Warszawa 2017; Hugon ze św. Wiktora, Didascalicon, czyli co i jak czytać, w: M. Frankowska-Terlecka, A wszystko to ze zdziwienia, Warszawa 2006, s. 278-315; Hugon ze św. Wiktora, Didascalicon de studio legendi. Księga III, 6-19, tłum. M. J. Janecki, Studia Antyczne i Mediewistyczne 15 [50] (2017), s. 167-176; Hugon ze św. Wiktora, O tym, że miłość Boga jest życiem serca, tłum. M. Zembrzuski, https://www.academia.edu/11575522/ 
Hugonowej interpretacji słynnych wersetów z Listu do Hebrajczyków, utworu reprezentatywnego dla twórczości duchowego mistrza i stanowiącego probierz jego oddziaływania na odbiorcę.

\section{Historia tekstu}

De Verbo Dei Hugona ${ }^{7}$ to krótki tekst stanowiący doskonały przykład dwunastowiecznej egzegezy uprawianej w paryskiej szkole, działającej w opactwie św. Wiktora ${ }^{8}$.

Hugonowe autorstwo tego tekstu nie było nigdy przedmiotem kontrowersji: incipit Semel locutus est Deus znajduje się w Indiculum ${ }^{9}$, wykazie jego dzieł sporządzonym przez opata Gildwina tuż po śmierci Hugona. Poświadczają je też wszystkie znane nam odpisy rękopiśmienne ${ }^{10} \mathrm{i}$ drukowane edycje utworów wiktoryna. Nigdy też dzieło to nie było przypisywane innemu autorowi. Również kryteria wewnętrzne tekstu zdradzają tematykę i stylistykę, nie budzącą zastrzeżeń co do autentyczności, w utworze występują charakterystyczne dla Hugona środki wyrazu oraz spójne z całością jego twórczości wątki doktrynalne.

O ile autorstwo tekstu nie budzi wątpliwości, o tyle autonomiczność i charakter De Verbo Dei nie są już tak oczywiste. W wydaniach drukowanych Opera omnia, od paryskiej edycji z 1526 roku aż do wersji podanej przez J.-P. Migne’a w kolekcji Patrologia Latina, tekst ten uważany był za część składową

Hugon_ze_\%C5\%9Bw._Wiktora_-_O_tym_\%C5\%BCe_mi\%C5\%82o\%C5\%9B\%C4\%87_ Boga_jest_\%C5\%BCyciem_serca [dostęp z dn. 9.09.2019].

7 Informacje dotyczące osoby i dzieła Hugona można znaleźć w publikacjach: P. Sicard, Hugues de Saint-Victor et son École, Turnhout 1991; P. Rorem, Hugh of Saint Victor, Oxford 2009; S. Janeczek, Hugon ze św. Wiktora. Myśl filozoficzna, „Powszechna Encyklopedia Filozofii", t. 4, Lublin 2003, s. 620-622.

8 Na temat szkoły św. Wiktora zob. H. Feiss, J. Mousseau (red.), A Companion to the Abbey of Saint Victor in Paris, Leiden-Boston 2017; J. Longère (red.), Labbaye parisienne de Saint-Victor au Moyen Age (Bibliotheca Victorina 1), Turnhout 1991; Poirel D. (red), L'école de Saint-Victor de Paris: Influence et rayonnement du Moyen Âge à l'époque moderne, Bibliotheca Victorina 22, Turnhout 2010.

9 Indiculum omnium scriptorum Magistri Hugonis de sancto Victore que scripsit, Oxford, Merton College 49, II, 14, opublikowane w: J. de Ghellinck, La table des matières de la première édition des oeuvres de Hugues de Saint-Victor, Recherches de science religieuse 1 (1910), s. 270-289, 385-396.

10 Szczególnie ms. Mazarine 717, Paris BN 14303, 12261, 13422, 15963, ms. Dijon 69, Troyes 554 . 
(numery 29-53) dzieła pt. De unione corporis et spiritus ${ }^{11}$. Jednak, jak zauważył B. Hauréau, między pierwszą częścią dzieła (która w istocie jest osobnym drobnym traktatem pod tytułem Quod natum est ex carne caro est) a De Verbo Dei nie istnieje żaden związek ${ }^{12}$, różnice zaś widoczne są nawet przy niezbyt wnikliwej lekturze. Krótsza redakcja naszego tekstu zachowała się w Hugonowych Miscellanea pod tytułem De verbi Dei efficacia ${ }^{13}$.

Struktura dzieła sprawia wrażenie, że mamy do czynienia z traktatem nieukończonym: wyraźnie można w nim wyróżnić prolog (I, 1-3), zaś reszta tekstu to rozwinięcie stanowiące komentarz do końcowych wersetów czwartego rozdziału i początku rozdziału piątego Listu do Hebrajczyków. Brak jest natomiast zakończenia, a wyjaśnienia dotyczące tych, którzy poddani są słabości wydają się nagle urwane i niepełne.

Wszystko to stawia pytanie o charakter tekstu i gatunek literacki. Nie wiadomo nic o okolicznościach jego powstania, ale jest możliwe, że mamy do czynienia $\mathrm{z}$ fragmentem liturgicznego kazania lub nauki, której w wiktoryńskim opactwie bracia mieli zwyczaj słuchać w ramach popołudniowej konferencji ${ }^{14}$. Kwestie podejmowane w czasie tych spotkań często były przyczynkiem do powstania innych dzieł wiktoryńskiego mistrza, a bracia niejednokrotnie domagali się pogłębienia i bardziej szczegółowego wyjaśnienia poruszanych zagadnień. Być może jest to reportatio, sporządzona przez jednego z braci lub studentów, którą mistrz mógł autoryzować i pozostawić wśród swoich zapisków odnalezionych w jego celi, gdy opuścił już ten świat. Są to hipotezy, których nie sposób dziś zweryfikować.

Łaciński tekst krytyczny dzieła opublikował R. Baron ${ }^{15}$ na podstawie pięciu najstarszych rękopisów, choć liczba wszystkich znanych nam odpisów jest znacznie większa ${ }^{16}$. Od francuskiego wydawcy pochodzi też tytuł ${ }^{17}$, podział

11 PL 177, kol. 289-294.

12 Por. B. Hauréau, Les oeuvres de Hugues de Saint-Victor, s. 191.

13 Hugon ze św. Wiktora, Miscellanea VI, 17, PL 177, 820A-821A.

14 Por. Hugo de Sancto Victore, De archa Noe I, I, 1-16, s. 3 oraz Liber ordinis Sancti Victoris Parisiensis, Turnhout 1984, 31-36..

15 Hugues de Saint-Victor, Six opuscules spirituels. Introduction, texte critique, traduction et notes par R. Baron, Paris 1969 (SC 155), s. 60-81.

16 R. Goy wylicza 24 rękopisy zawierające nasz tekst, zob. R. Goy, Die Überlieferung, s. 91, natomiast P. Sicard informuje o istnieniu kolejnych trzech, por. P. Sicard, Iter victorinum, s. 402. Do tego należałoby dodać odpisy De unione corporis et spiritus, zawierające interesujący nas utwór. Goy podaje je w liczbie 18 (zob. Die Überlieferung, s. 9598), a Sicard uzupełnia ten wykaz o kolejne 16 odpisów (zob. Iter victorinum, s. 183-185).

17 Warianty tytułu: Quomodo sermo dei unus est; Sermo de eo quod scriptum est unus sermo dei; de refectione verbi dei; Super versículo Apostoli: Vivus est sermo dei; de verbi 
tekstu na części i paragrafy oraz ich numeracja. Za podstawę przekładu, który prezentujemy poniżej, przyjęto tekst ustalony właśnie przez tego wybitnego znawcę twórczości wiktorynów.

\section{Szata językowa}

Tym, co przyciąga odbiorcę Hugonowych traktatów, jest - prócz ponadczasowych treści - sposób ich przedstawienia ${ }^{18}$. Pismo De Verbo Dei zdradza intencję autora, by zgodnie z klasycznymi wymaganiami retoryki nie tylko pouczyć odbiorców (docere), lecz także poruszyć ich wnętrze (movere) oraz zachwycić (delectare).

Z językowego bogactwa Hugon wydobywa zasoby słów zestawianych z sobą w całej różnorodności figur retorycznych. Odsłania ukryte znaczenia, korzysta z wieloznaczności wyrażeń, czym niekiedy zaskakuje. Szyk wyrazów w zdaniu, układ zdań i ich relacje w stosunku do siebie zdradzają zamiar głębokiego oddziaływania na odbiorcę.

Spośród figur retorycznych (głównie figurae elocutionis ${ }^{19}$ ) Hugon chętnie wybiera anaforę, jak i epiforę, a także ich połączenie (symploka).

Na uwagę zasługuje epifora, ponieważ Hugon stosuje ją wtedy, gdy chce podkreślić wagę słowa kluczowego dla zrozumienia treści wypowiedzi, jak na przykład w zdaniu, w którym uzasadnia jedność Bożej mowy:

Unus est ergo sermo Dei, quia unum est Verbum Dei. (I.1)

Jedna jest więc mowa Boga, bo jedno jest Słowo Boga.

Zwróciwszy naszą uwagę na tego, kto wypowiada Słowo, Hugon kieruje ją następnie na jedność Bożej mowy, gdy w lapidarnym, eliptycznym zdaniu mówi:

sive sermone dei efficacia; ex de unione corporis et animae; de verbo dei, zob. Goy, Die Überlieferung, s. 91.

$18 \mathrm{O}$ języku Hugona pisali m.in. C. Giraud, Du silence à la parole: Le Latin spirituel d'Hugues de Saint-Victor dans le "De vanitate mundi", AHDLMA 77 (2010), s. 7-27, L. Negri, Lettura stilistica di Ugo di San Vittore: il "De arrha animae", Convivium 24 (1956), s. 129-140, R. Baron, Le style de Hugues de Saint-Victor, w: Études sur Hugues de SaintVictor, Bruges 1963, s. 91-120, językowi egzegezy św. Tomasza z Akwinu publikację poświęcił P. Roszak, Between Dialectics and Metaphor: Dynamics of Exegetical Practice of Thomas Aquinas, Angelicum 3(2013), 507-534.

19 Zob. H. Lausberg, Retoryka literacka, s. 346-416, M. Korolko, Sztuka retoryki, s. 111-116. 
Et ideo vere unus, quia unius unus. (I.1)

A dlatego prawdziwie jedna, że [jest] jedną Jedynego.

Retoryczny walor tego miejsca wzmocniony jest przez zestawienie dwóch podobnie brzmiących słów (unius unus), z których jedno ma nieznacznie zmienioną formę (paronomazja), co przesuwa akcent $\mathrm{z}$ jedności przedmiotu (unus sermo) na jedność podmiotu (unus Deus).

Symploka niejako obejmuje wypowiedź. Hugon używa tej figury, gdy chce wykazać, że oko Boże obejmuje wszystko:

et intima, quia in omnibus est,

et subtilia, quia perspicax est [...] (IV.1)

i to, co najgłębsze, bo jest we wszystkim,

i to, co subtelne, bo jest przenikliwe.

Wśród innych figur, tworzonych „przez dodanie” (figurae per adiectionem), prócz anafory i epifory spotkamy w utworze sąsiadujące $\mathrm{z}$ sobą podwojenie tej samej formy (anadiploza);

pontifex est ut offerat Deo vota populi, et magnus: magnus secundum divinitatem [...] (V.3)

jest arcykapłanem, aby składać Bogu ofiary ludu, a jest potężny: potężny co do bóstwa [...]

jak również repetycję w postaci zmienionej formy werbalnej (synonimia):

Ipse enim et voluntates nostras intelligit, et cogitationes videt, et intentiones comprehendit. (III)

On bowiem zna nasze pragnienia i widzi myśli, i pojmuje zamiary.

Synonimia służy amplifikacji, rozszerzeniu wypowiedzi. Wybrane przez Hugona czasowniki bliskoznaczne nie zostały tu użyte przypadkowo ani pleonastycznie, lecz mają za zadanie uwrażliwić odbiorcę na znaczeniowe odcienie w każdym wyrażeniu.

Ukoronowaniem inklinacji Hugona do ozdabiania wypowiedzi figurami per adiectionem jest nagromadzenie (enumeracja), tu połączona $\mathrm{z}$ polisyndetonem i anarofą:

nec operimentum tegit, nec velamen protegit, nec paries intercludit, nec caligo abscondit nos ab oculis eius. (IV.3) 
ani okrycie nie osłoni, ani welon nie zasłoni, ani mur nie zamknie, ani mrok nie ukryje nas przed oczami Jego.

Jak ważnym dla Hugona jest temat przenikliwości „oka Bożego”, można się przekonać, zwracając uwagę na ilość i jakość figur ilustrujących ten temat.

Tam, gdzie Hugon chce być zwięzły lub chce oddziaływać na odbiorcę przez zaskoczenie, stosuje figurae per detractionem (figury tworzone „przez odjęcie”), takie jak elipsa, asyndeton, zeugma.

Połączenie bezspójnikowe (asyndeton) dodaje wygłaszanym słowom dynamiki. Hugon używa go dla zobrazowania komentowanego wersetu: Żywa jest mowa Boża i skuteczna, i przenikliwsza niż wszelki miecz obosieczny (Hbr 4,12):

Non mutatur in promisso, non deficit in facto, non fallitur in iudicio. (II)

Nie zmienia się w obietnicy, nie zawodzi w czynie, nie myli się w osądzie.

Veraciter promittit, fortiter facit, subtiliter discernit. (II)

Obiecuje prawdziwie, działa skutecznie, rozstrzyga wnikliwie.

Podobny efekt daje zeugma, jak zaobserwowano to w opisie "trojga oczu”, gdzie Hugon - akcentując nieograniczoność możliwości oka Bożego wiąże wszystkie elementy podporządkowując je jednemu czasownikowi:

oculus cordis et extima et intima corporum, sed tantum extima cordium; oculus vero Dei extima simul et intima, non solum corporum sed etiam cordium capit. (IV.2)

oko serca i to, co na zewnątrz, i to co wewnątrz ciał, lecz tylko to, co na zewnątrz serc, oko zaś Boga dostrzega jednocześnie i to, co na zewnątrz, i to, co wewnątrz, nie tylko ciał, lecz także serc.

Hugon niekiedy stosuje powtórzenia wyrazów, niekiedy - usuwa je tam, gdzie byłyby oczekiwane. Ale tym, co charakteryzuje jego prozę, jest dbałość o paralelizm myśli, obrazowany paralelizmem składniowym. Zdania lub ich człony układane są w taki sposób, by można było dostrzec ich wzajemną korespondencję:

Vivus, quia non mutatur.

Efficax, quia non deficit.

Penetrabilis, quia non fallitur. (II)

Żywa, bo się nie zmienia.

Skuteczna, bo nie zawodzi.

Przenikliwa, bo się nie myli. 
Każde z trzech zdań charakteryzuje się identyczną budową. Konstrukcje tego typu są bardzo częste w utworze De Verbo Dei. Ich paralelizm jest wzmacniany przez homofonię zakończeń czasowników (homoioteleuton) lub rzeczowników (homoioptoton):

Quia igitur vivus est sermo Dei, credamus eum vera promittere; quia efficax est, speremus eum promissa perficere (III)

Ponieważ zatem mowa Boża jest żywa, wierzmy, że On obiecuje to, co prawdziwe; ponieważ jest skuteczna, ufajmy, że spełni to, co obiecane.

Promissio eius oblivione non moritur nec intentione mutatur.

Operatio eius difficultate non vincitur. Iudicium eius ambiguitate non fallitur. (II)

Jej obietnica nie ginie w zapomnieniu ani co do zamiaru się nie zmienia.

Jej działanie nie ponosi porażki z powodu trudności. Jej osąd się nie myli z powodu dwuznaczności.

Zdania zestawiane przez Hugona są różne co do długości. Jednak kiedy Hugon stawia pytanie dotyczące jedności Słowa Bożego, łączy zdania o zbliżonej liczbie sylab, które w pierwszej części zestawienia są identyczne pod względem metrycznym. W ten sposób Hugon uzyskał izokolon, którego efekt wzmocniony został również przez homioieteleuton:

Si enim vere sermo Dei unus creditur, quomodo multi sermones eius dicuntur? (I)

Jeśli bowiem sądzi się, że naprawdę Boża mowa jest jedna, w jaki sposób mówi się, że Jego mów jest wiele?

Użycie izokolonu ozdabia wypowiedź, wprowadza rytm. Stosując tę figurę Hugon zaznacza miejsce ważne dla dalszych rozważań.

W celu wydobycia głębszego sensu rozwijanych myśli Hugon często zestawia z sobą dwa obrazy, przeciwstawiając je ze sobą. Dla wzmocnienia efektu antytezy Hugon tworzy zdania paralelne syntaktycznie. Niekiedy korespondencja między członami jest tak ścisła, że obejmuje nie tylko poszczególne części zdania, lecz nawet użycie przypadków gramatycznych:

quia ille qui per sapientiam suam intus secreta nostra subtiliter intelligendo discernit, foris per doctrinam suam utiliter nos illuminando eodem intelligere facit. (III) 
bo ten, kto wewnątrz przez mądrość swoją, dokładnie poznając osądza nasze tajemnice,

na zewnątrz przez naukę swoją ku pożytkowi nas oświecając, sprawia, że my poznajemy to samo.

W przytoczonym zdaniu zestawione są dwa rodzaje przenikającego działania Bożej mowy. Przeciwstawione sobie jest to, co wewnątrz i to, co na zewnątrz. Mocno zaznaczone są kontrasty: intus - foris (na zewnątrz - wewnątrz), per sapientiam - per doctrinam (dzięki mądrości - dzięki nauce). Podobieństwem brzmieniowym Hugon posługuje się zestawiając participia w tym samym przypadku gramatycznym (homoioptoton): intelligendo - illuminando (rozumiejąc - oświecając) oraz przysłówki: subtiliter - utiliter (wnikliwie - z pożytkiem).

Powyższe przykłady nie wyczerpują bogactwa wykorzystanych przez Hugona środków retorycznych, trudnych do oddania w języku innym niż język oryginału. Można zapytać, czy ilość zastosowanych figur nie obciąża wykładu, nie czyni trudniejszym jego zrozumienia. Trzeba jednak pamiętać, że retoryka należała do trivium $\mathrm{w}$ modelu średniowiecznego kształcenia i stosowanie jej osiągnięć było czymś oczekiwanym przez odbiorców. Styl Hugona z pewnością nie uchybia zasadzie stosowności, z pewnością także był skutecznym środkiem oddziaływania na odbiorców i mimo upływu wieków zachowuje swą moc także dziś.

\section{Zagadnienia teologiczno-filozoficzne}

Niewielki tekst De Verbo Dei zawiera niezwykłe bogactwo treści. Rozważania Hugona osnute są wokół wymownego passusu z Listu do Hebrajczyków ${ }^{20}$, rozpoczynającego się od słów: „Albowiem mowa boża jest żywa i skuteczna i przenikliwsza, niż wszelki miecz obosieczny i dosięga aż do rozdzielenia duszy i ducha, stawów też i szpiku i rozsądza myśli i zamiary serca"21.

Wyjaśnienie dokonane przez paryskiego mistrza ukazuje głębokie znaczenie tekstu biblijnego, przy czym Hugon pomija sens dosłowny i zagadnienia historyczno-krytyczne z nim związane, a skupia się na sensie duchowym, dostarczając znakomitego przykładu interpretacji alegoryczno-tropologicznej. Wykład Hugona ma na celu ukazanie natury i właściwości Słowa Bożego oraz

20 Hbr 4,12-5,2.

21 W przekładzie posługiwano się tłumaczeniem Jakuba Wujka według reportacji typu C (dopóki zgadzało się ono z tekstem De Verbo Dei), ponieważ najlepiej pomaga ono współczesnemu czytelnikowi uchwycić właśnie te sensy, które wydobywa Hugon, Pismo święte Starego i Nowego Testamentu, Kraków 1962. 
skutków jego oddziaływania na życie człowieka. Średniowieczny mistrz podejmuje takie kwestie, jak: jedność i przymioty Słowa Bożego, ludzka natura oraz konstytuujące ją ciało, duch i umysł, symboliczna typologia różnych rodzajów poznania, dialogiczny charakter Bożej mowy wraz z pośredniczącą rolą Wcielonego Słowa, tajemnica kapłaństwa Chrystusa oraz powinności przełożonych w Kościele. Analiza każdego z powyższych zagadnień pozwoli uzyskać tematyczną mapę utworu De Verbo Dei.

\subsection{Boża mowa. Jej jedność i przymioty}

Hugon rozpoczyna odsłanianie sensu tekstu biblijnego od uzasadnienia jedności Bożej mowy. Bożą mową (sermo Dei) jest jedno, zrodzone Słowo Boże (Verbum Dei). Pismo święte (w dostępnej Hugonowi łacińskiej wersji) zawiera wprawdzie miejsca, w których podaje się wyraz "mowa” w liczbie mnogiej (sermones), ale skoro Bóg przemawia przez ludzi w różnych okolicznościach czasowych i przestrzennych, to z konieczności skutkuje to zwielokrotnieniem słów, co jednak nie narusza jedności przekazu Bożego. Wiktoryński egzegeta eksponuje tajemnicę Słowa Bożego, które jeden raz przyoblekło się w ludzkie ciało w kulminacyjnym momencie historii zbawienia, a które, odziane w dźwięki ludzkiego głosu, przychodzi do nas każdego dnia. Hugon zarysowuje tu obecne w całym traktacie rozróżnienie między tym, co zewnętrzne, a tym, co wewnętrzne. Słowo Boże, dostrzegane jedynie z zewnątrz, może zostać zlekceważone, a nawet uśmiercone. Chroni przed tym jedynie wewnętrzny smak, który pozwala zakosztować w rozkoszy Bożego orędzia, ożywiającego zasłuchane serce.

Powyższe exordium, podkreślające głębię podejmowanego tematu, przygotowuje odbiorców do rozważań nad przymiotami Słowa Bożego, wymienionymi w Liście do Hebrajczyków. Żywość, skuteczność i przenikliwość wyrażają niezmienność, niezawodność i nieomylność Bożej mowy w obietnicach, działaniu i sądach, a dla człowieka stanowią podstawę wiary, nadziei i bojaźni. Uwaga Hugona skupia się na wnikliwości sądów, działających jak miecz obosieczny, który rozdziela jednak nie materię, ale duszę i ducha.

\subsection{Antropologia teologiczna}

Interpretacja słów o zdolności Słowa Bożego do rozdzielenia duszy i ducha stanowi centralną i najobszerniejszą część rozważań Hugona. Za ich podstawę służą różne ujęcia natury ludzkiej ${ }^{22}$. Hugon wyróżnia w niej ciało, ducha

$22 \mathrm{Na}$ temat czterech ujęć: ontologicznego, psychologicznego, symbolicznego i moralnego zob. R. Baron, Six opuscules, s. 20. 
i umysł (caro, spiritus, mens) ${ }^{23}$. Każdemu z elementów przypisane są określone domeny, wpisane w porządek życia psychicznego: ciału - przyjemność (delectatio), duchowi - myślenie (cogitatio), a umysłowi - rozsądzanie (discretio). Trzecie ujęcie ma charakter symboliczny - Hugon dokonuje alegorycznej interpretacji ról bohaterów biblijnej sceny kuszenia. Wąż symbolizuje przyjemność, Ewa - myślenie, Adam - rozsądzanie. Czwarte ujęcie odkrywa sens moralny: w przyjemności tkwi pożądliwość nadmiaru (superfluitatis concupiscentia), w myśleniu jest zapobiegliwość o to, co niezbędne (necessitatis providentia), a rozsądzaniu przypisany jest wyrok prawdy (veritatis sententia). Między tymi elementami zachodzą wzajemne powiązania i wpływy: przyjemność popycha zapobiegliwość do zbytku. Zapobiegliwość zaś, związana z niższymi częściami, odwodzi rozum (ratio) od wyroku prawdy. Opis ten uzasadnia stan kondycji ludzkiej po grzechu, kiedy działanie rozumu utraciło swą zdolność pewnego rozpoznawania prawdy ${ }^{24}$. Przenikliwość Słowa Bożego pozwala na rozdzielenie owych powiązanych z sobą, ciążących ku niższym częściom elementów. Pierwsze rozdzielenie następuje między wężem a Ewą, symbolizującym cielesność (inaczej duszę) $)^{25}$ i ducha; przyjemność i myślenie, zbytek i niezbędność, a zatem element pożądawczy i racjonalny w człowieku. Drugiego podziału Słowo Boże zdolne jest dokonać między Ewą a Adamem, czyli w porządku psychologicznym między myśleniem a zamiarem lub rozsądzaniem, czy też na poziomie moralnym - między roztropnością ciała a wyrokiem prawdy.

23 Źródła antropologicznej koncepcji Hugona ukazuje C. Németh, Contemplation and the Cognition of God, s. 41-68.

24 Zob. De sacramentis I,x,2, PL 176, 329C.

25 Termin anima (dusza) utożsamiony jest tu $\mathrm{z}$ cielesnością i naturą zwierzęcą (carnalitatem, sive animam vel animalitatem). Dla Hugona dusza jest znakomitszą częścią człowieka (pyta on nawet: Quid enim magis est homo quam anima? De sacramentis II,I,11, PL 176, 407D). Jest on stworzony na obraz i podobieństwo Boże, które są właśnie w duszy (De sacramentis I,vi,2, PL 176, 264C). Anima i corpus nie tworzą substancjalnej jedności, ciało jest niejako przyłączone do duszy i tylko w ten sposób ma udział w byciu osobą (ibidem, 408D). W utworze De Verbo Dei zaakcentowane zostało subtelne rozróżnienie między duszą (anima) a duchem (spiritus). Dokładniejsza dystynkcja podana jest w utworze Super Canticum Mariae, w którym Hugon podkreślając tożsamość duszy i ducha, zaznacza jednocześnie, że pojęcie „duch” odnosi się do substancji, natomiast „dusza” do funkcji ożywiania. Termin „dusza” przynależy do istot posiadających ciało, dlatego nie można duszami nazwać duchów czystych, ale można tak nazwać zwierzęta. Dusza zaś ludzka może być nazywana i duszą, i duchem. Duszą, o ile jest życiem ciała, duchem, o ile jest obdarzoną jest rozumem substancją duchową (s.42-44), por. A.M. Piazzoni, Il „De unione spiritus et corporis", s. 879. Na temat koncepcji duszy u Hugona zob. S. Swieżawski, Homo platonicus, s. $278-282$. 
Słowa dotyczące oddzielenia stawów i szpiku pozwalają Hugonowi na alegoryczne przedstawienie teorii ludzkiego aktu, który rodzi się w niewidzialnej intencji, a ujawnia zewnętrznym czynem. Poszczególnym fazom działania przypisane są coraz bardziej zewnętrzne elementy ciała ludzkiego: zamiar to szpik, myśli to stawy i kości, pragnienia to mięśnie, a skóra to uczynki. Zamiary są jądrem myśli, a myśli - niekiedy przyczyną, niekiedy zaś skutkiem pragnień. Myśli, symbolizowane w tekście biblijnym przez stawy, stanowią trudną, dla człowieka wręcz niedostępną materię do osądzenia, ale jeszcze subtelniejszego wglądu wymagają ukryte w nich, niby szpik w kościach, zamiary. W ten sposób Hugon uzasadnia wzmiankę autora natchnionego o Słowie Bożym, zdolnym do rozdzielenia stawów i szpiku. Tylko bowiem Słowo Boże wnika swą mądrością w ludzkie wnętrze, na zewnątrz zaś udziela człowiekowi oświecenia, by sam mógł siebie zrozumieć.

\subsection{Troje oczu: symboliczna epistemologia}

Biblijny werset: I żadne stworzenie nie jest niewidzialne przed obliczem jego, lecz wszystkie rzeczy sq obnażone i odkryte oczom tego, przed którym odpowiemy ${ }^{26}$ prowokuje Hugona do nakreślenia teorii o możliwościach ludzkiego i boskiego poznania. Ludzką władzę poznawczą metaforycznie określa on mianem oka. Antynomia między tym, co dostrzegalne zewnętrznie, a tym, co możliwe do uchwycenia wewnętrznie stanowi linię demarkacyjną między polem działania oka ciała (oculus carnis) a możliwościami poznawczymi oka serca, zwanego także okiem umysłu (oculus cordis, oculus mentis) ${ }^{27}$. Są jednak głębie, gdzie ani oko ciała, ani oko serca nie jest w stanie dotrzeć w obecnej kondycji człowieka, w którego historii pojawił się grzech. Symboliczna nauka o trojgu oczu, stanowiąca zręby Hugonowej teorii poznania, jest rozwinięciem jego antropologii, wpisanej w proces historyczny ${ }^{28}$. Hugon wyróżnia trzy momenty: okres rajski (opus conditionis), grzech i okres odnowienia pierwotnej natury człowieka odnowa w człowieku obrazu i podobieństwa do Boga (opus restaurationis) ${ }^{29}$. Takie ujęcie historii zbawienia wpływa na całokształt teologicznego myślenia

26 Hbr 4,13.

27 Jak podkreśla R. Baron, pojęcie cor użyte jest tutaj zgodnie ze swym biblijnym znaczeniem, które w kulturze semickiej stanowiło synonim myśli, zob. R. Baron, Six opuscules, s. 22.

28 Por. De sacramentis I,x,2, PL 176, 329C-330B; Super Hierarchiam, III, II, 3, s. 472.

29 De sacramentis, Prol., PL 176, $183 \mathrm{~B}$. 
Hugona ${ }^{30} \mathrm{i}$ implikuje kolejne rozwiązania. Człowiek został stworzony na Boży obraz i podobieństwo (ad imaginem et similitudinem Dei) ${ }^{31}$ i będąc w stanie pierwotnej integralności cieszył się doskonałym poznaniem Boga ${ }^{32}$. Grzech spowodował jednak, iż poznanie to zostało zaburzone. W stanie rajskim dusza ludzka otrzymała od Boga troje oczu: oko ciała (oculus carnis), dzięki któremu mogła ona widzieć świat i wszystko, co się na nim znajduje, oko rozumu (oculus rationis), dzięki któremu widziała siebie i wszystko, co jest w niej samej, oraz oko kontemplacji (oculus contemplationis), dzięki któremu mogła w sobie widzieć Boga ${ }^{33}$. Po upadku otwarte jest jedynie oko ciała, oko rozumu jest pozbawione swej ostrości, a oko kontemplacji jest ślepe ${ }^{34}$. W De Verbo Dei o oku kontemplacji nie ma mowy. Pojawia się natomiast oculus Dei, oko będące symbolem wszechogarniającej wiedzy Boga, dla którego nic nie jest ukryte. To zatem, co nieosiągalne dla ludzkich zdolności poznawczych, dostępne jest poznaniu Bożemu. Tu znajduje się clou wywodu wiktoryna - magnum sacramentum, do którego zgłębienia zapraszał nas w prologu: Słowo Boże jest jednym z sakramentów służących odnowie pierwotnego stanu ludzkiej kondycji ${ }^{35}$. To, czego człowiek nie może poznać wewnętrznie na mocy własnej natury dotkniętej skutkami grzechu, zostaje mu objawione z zewnątrz przez łaskę, by poszerzyć pole jego możliwości poznawczych. W konsekwencji Słowo Boże to balsam dla oculus cordis, remedium na ślepotę, którą zostało ono dotknięte wskutek grzechu. Kontakt ze Słowem ma właściwości uzdrawiające z niewiedzy, a słuchający je człowiek wyostrza sobie duchową percepcję i staje się zdolny wniknąć w same intencje własnych działań. W ten sposób w okresie odnowienia, ale przed nastaniem okresu eschatologicznego - kiedy oko kontemplacji na nowo zostanie otwarte - Słowo Boże jest jednym z sakramentów wiary chrześcijańskiej, wspomagającym oculus rationis i zastępującym częściowo oculus contemplationis.

30 Temu tematowi publikację poświęcił B.T. Coolman, The Theology of Hugh of St. Victor. An Interpretation, Cambridge 2010, por. C. Blessing, Sacramenta, s. 48-49.

31 Rdz 1,25-27, De sacramentis I,VI,2, PL 176, 264 CD.

32 De sacramentis I,VI,11, PL 176, 270 BC.

33 De sacramentis I,x,2, PL 176, 329C-330B.

34 Super Ierarchiam Dionysii III, II, 3, s. 472.

35 Wszystkie treści zawierające się w Piśmie świętym dotyczą opus restaurationis, zob. De scripturis et scriptoribus sacris, PL 175, 11 C, De sacramentis, Prol., PL 176, 183A, C. Blessing, Sacramenta, s. 50. 


\subsection{Dialogiczny charakter Bożej mowy}

W interesujący sposób Hugon wyjaśnia słowa: ad quem nobis sermo ${ }^{36}$, opierając się na wieloznaczności tego eliptycznego zdania. Ad quem można bowiem rozumieć dwojako: możemy naszą mowę kierować albo do Boga, albo do Jego mowy, czyli Słowa. Pierwszą jest jednak zawsze Boża mowa kierowana do nas. Hugon podejmuje na nowo antytezę: wewnątrz - na zewnątrz. Mowa kierowana do człowieka zewnętrznie przekazywana jest przez głoszenie Słowa Bożego, ta kierowana do niego wewnętrznie to Boże natchnienie, dokonujące się albo przez naturę, albo przez łaskę ${ }^{37}$. Hugon nawiązuje do zasadniczego dla swej myśli teologicznej podziału na dzieło stworzenia i działo odkupienia oraz kondycji człowieka przed upadkiem i po nim. Mowa Boża kierowana do stworzonych, to natchnienie poznania dobra, które zostało wpisane w ludzką naturę. W dziele odkupienia natomiast zaczyna działać łaska, by doprowadzić ludzi do zbawienia i podsuwa im niejako umiłowanie dobra. Pary pojęć: dzieło stworzenia - dzieło odkupienia, natura - łaska stanowią nawiązanie do głównej myśli Hugona, rozwijanej również w innych dziełach, w tym - w jego najważniejszym utworze De sacramentis christianae fidei ${ }^{38}$.

Nasza mowa kierowana ku Bogu, czyli modlitwa, powinna szukać rady o sposób postępowania, ponieważ zdamy sprawę z uczynków. Interpretując obraz z Apokalipsy ${ }^{39}$ Hugon rozwija metaforę ksiąg, rozumianych jako ludzkie serca, oraz Księgi Życia - symbolizującej mądrość Bożą. Księgi ludzkich serc powinny być pisane na wzór Bożej księgi, gdyż ludzkie serca stworzone są na podobieństwo Bożej mądrości ${ }^{40}$. Hugon poucza, iż nasze księgi powinno się poprawiać według Bożej księgi, aby w czasie owego ostatecznego kolacjonowania (ultima collatio) okazały się wierne oryginałowi. Ta piękna metafora zdaje się nawiązywać do znanej Hugonowi praktyki kopiowania ksiąg. W opactwie św. Wiktora działało bowiem prężne skryptorium, w którym zakonnicy z kunsztem powielali teksty i sprawdzali zgodność swego odpisu przez zestawienie $\mathrm{z}$ archetypem ${ }^{41}$.

36 Hbr 4,13, w tłumaczeniu Wujka: przed którym odpowiemy, gdzie zupełnie znika podstawowe znaczenie kluczowego dla tekstu słowa sermo.

37 Por. De sacramentis I, III, 34; Misc. I, 63; Sententiae de divinitate, s. 95.

38 Por. C. Blessing, Sacramenta, s. 48-66, De sacramentis, PL 176, 173-618B.

39 Ap. 20, 12.

40 Por. De sacramentis I,Vi,2, PL 176, 264CD.

41 Zob. F. Gasparri, Scriptorium et bureau d'écriture de l'abbaye Saint-Victor de Paris, s. $119-139$. 


\subsection{Chrystus Najwyższym Kapłanem}

Druga z interpretacji słów: ad quem nobis sermo prowadzi Hugona do osoby Chrystusa jako pośrednika w modlitwach do Boga. Ponownie autor nawiązuje do tematu łaski, której działania nie powstrzymuje nawet ludzka nędza. A jak Hugon pisze w innym miejscu, modlitwa wznosi się na dwóch skrzydłach; na skrzydłach ludzkiej nędzy i miłosierdzia Odkupiciela ${ }^{42}$. Hugon podnosi temat obecny w Liście do Hebrajczyków: Chrystus jest ustanowionym przez Boga Najwyższym Kapłanem i to takim, który potrafi współczuć naszym słabościom. Współodczuwanie jest dla Hugona cechą pełnego człowieczeństwa i wyrazem miłości ${ }^{43}$. Teolog ze św. Wiktora podkreśla trzy momenty, w których dał się słyszeć głos Boga nad Chrystusem: W czasie Jego chrztu w Jordanie, kiedy w interpretacji Hugona nastąpiło wybranie, następnie na górze Tabor w czasie przemienienia, gdzie dokonało się ustanowienie Chrystusa kapłanem oraz w dniach przed Męką, gdy na prośbę Jezusa „Ojcze, wsław imię Twoje!” rozległ się głos z nieba „Już wsławiłem i jeszcze wsławię” (J 12,28), co dla Hugona było znakiem uznania i umocnienia w kapłańskiej godności. Wiktoryn zestawia wspomniane momenty z punktem kulminacyjnym Chrystusowego kapłaństwa, jakim było wydarzenie Zmartwychwstania.

\subsection{Kapłaństwo służebne na wzór kapłaństwa Chrystusa}

Traktat De Verbo Dei otwierają rozważania nad jednością Wcielonego Słowa, a zamykają implikacje pastoralne komentowanego tekstu dla rzeczywistości eklezjalnej. Wykład podaje oparte na znanej opozycji: wewnątrz - na zewnątrz kryteria wyboru kapłanów i przełożonych wspólnot chrześcijańskich w ich podwójnej roli legata: raz reprezentującego Boga przed ludem, a raz wstawiającego się za ludem przed Bogiem. O tej funkcji powiedziane jest: który by mógł współboleć z tymi, co nie wiedza i błądza, gdyż i sam poddany jest słabości (Hbr 5,2). Hugon wyjaśnia, co to znaczy być poddanym słabości. Medytacja nad mocą Słowa Bożego w postaci, jaka została nam przekazana przez wydawcę, w tym miejscu się kończy.

Wymowny passus z Listu do Hebrajczyków odczytany oczyma Hugona pozwala odkryć nie tylko własny głęboki sens, lecz także przyjrzeć się wewnętrznemu bogactwu tego, kto go komentuje. Wiktoryński egzegeta uwydatnia moc Słowa Bożego, przedstawia doktrynę antropologiczną, snuje rozważania natu-

42 De uirtute orandi, s.128.

43 Por. De quatuor voluntatibus in Christo, PL 176, 842B, zob. B.T. Coolman, Hugh of St. Victor on "Jesus wept”, s. 543-544. 
ry psychologicznej i moralnej, dotyka zagadnień związanych z możliwościami poznawczymi człowieka, konstatując, iż tylko Słowo Boże może dotrzeć do obszarów całkowicie dla ludzkiego wglądu niedostępnych. W oparciu o swą historiozbawczą wizję opus conditionis i opus restaurationis dotyka kwestii natury i łaski, modlitwy i pośredniczącej roli Chrystusa Najwyższego Kapłana. Nie zapomina przy tym nawiązać do powinności kapłanów i przełożonych w Kościele. W ten sposób prowadzi myśl od tajemnicy Wcielonego Słowa do tajemnicy Kościoła. Oto zapowiedziane w prologu magnum sacramentum.

Bogactwo treści, zawartych w skromnym opusculum, wciąż zachowuje swą moc oddziaływania na odbiorcę. O tym, że wiktoryńskie źródła nadal inspirują i służą lepszemu zrozumieniu nas samych, przekonuje stałe zainteresowanie współczesnych, podejmujących przemyślenia nie tylko spekulatywne, lecz także praktyczne, odwołujące się do osiągnięć średniowiecznego mistrza ${ }^{44}$.

\section{Przekład}

\section{O Słowie Bożym}

1. Raz rzekł Bóg ${ }^{45}$, ponieważ jedno zrodził Słowo, przez które uczynił wszystko. Słowo to jest Jego mową. Jedna jest więc mowa Boża, bo jedno jest Słowo Boże. A dlatego prawdziwie jedna, że jest jedną Jedynego; nie obejmuje ona złożonych wypowiedzi, lecz w pełni wyraża się jednym i prostym słowem.

Dlaczegóż więc w psalmie jest powiedziane: Abyś się okazał sprawiedliwym $w$ mowach Twoich ${ }^{46} \mathrm{i}$ w innym miejscu: Ożyw mię, abym strzegł mów Twoich ${ }^{47}$. Jeśli bowiem sądzi się, że naprawdę mowa Boga jest jedna, jakim sposobem mówi się, że Jego mów jest wiele?

Trzeba jednak wiedzieć, że Bóg inaczej przemawia przez ludzkie usta, inaczej - przez siebie samego. To bowiem, co Bóg mówi pośród ludzi przez ludzi,

44 Por. K. Grzywocz, Rozwój duchowy: rozważania w świetle Hugona od św. Wiktora, w: Aktywizacja w katechezie: szansa czy zagrożenie?, R. Chałupniak, J. Kostorz, W. Spyra (red.), Opole 2002, s. 41-49.

45 Ps 61(62),12; cytaty i numeracja psalmów zgodnie Biblią w przekładzie ks. Jakuba Wujka (tam, gdzie tekst łaciński zgadzał się z przekładem).

46 Ps 50(51),6.

47 Ps 118(119), 17. 
wszystko niemal poświadcza Pismo zarówno Starego, jak i Nowego Testamentu. Mówi więc przez ludzi - mówi przez siebie; wiele mów - przez ludzi, jedną przez siebie samego. Lecz jakiekolwiek wypowiedział przez ludzkie usta, jedna w nich wszystkich była to mowa, a wszystkie w tej jednej są jednym, a bez niej nie mogą być one wypowiadane w dowolnym miejscu czy czasie. Przyjrzyjmy się zatem wielkiemu sakramentowi.

2. Słowo Boże, odziane w ludzkie ciało, jako widzialne ukazało się tylko raz, a teraz Ono samo, okryte ludzkim głosem przychodzi do nas każdego dnia. A choć inaczej daje się poznać ludziom za pośrednictwem ciała, a inaczej za pośrednictwem ludzkiego głosu, to jednak w pewien sposób tu należy rozpoznawać głos Słowa tak, jak tam - ciało Boga. Człowieczeństwo Chrystusa również źli i niewierzący mogli nie tylko widzieć, lecz także i zabić i aż dotąd każdego dnia Bożej mowy słuchają z zewnątrz i nią gardzą. I jak tamci nie śmieliby zabić człowieka, gdyby byli w stanie rozpoznać Boga, tak także i ci nie odrzucaliby słyszanych słów Bożych, gdyby wewnętrznym smakiem mogli kosztować ich mocy.

3. Mowa przeto Boża jest $\dot{z} y w a^{48}$, ponieważ jest w niej życie. W niej to, co na zewnątrz pobudza słuch, to, co wewnątrz ożywia serce. W niej to, co wpada do uszu, to, co wsącza się do serca. To, co jest na zewnątrz, przemija; to, co jest wewnątrz - nie podlega zmienności. To, co na zewnątrz rozwijane jest przez ciąg słów, wewnątrz jest dyktowane przez niezmienną prawdę. Dlatego, mówi, niebo i ziemia przemina, ale słowa moje nie przemina ${ }^{49}$. Tam właśnie nie przeminą, gdzie nie ma tego, co przemijające. Bo jak jedno słowo w wielu nie doznaje podziału, tak wiele w jednym słowie nie podlega zmianie.

Wyjaśniwszy przeto zwięźle to, co dotyczy mowy Bożej, rozważmy teraz słowa Apostoła.

1. Żywa jest, rzecze, mowa Boża i skuteczna, i przenikliwsza, niż wszelki miecz obosieczny ${ }^{50}$. Żywa, bo się nie zmienia. Skuteczna, bo nie zawodzi. Przenikliwa, bo się nie myli. Nie zmienia się w obietnicy, nie zawodzi w czynie, nie myli się w osądzie. Jej obietnica nie ginie w zapomnieniu ani co do zamiaru się nie zmienia. Jej działanie nie ponosi porażki z powodu trudności. Jej osąd nie myli się z powodu dwuznaczności. Obiecuje prawdziwie, działa skutecznie, rozstrzyga wnikliwie. Żywa jest Boża mowa, byś wierzył, skuteczna, byś

\footnotetext{
48 Hbr 4,12 .

49 Mt 24,35.

50 Hbr 4,12.
} 
ufał, przenikliwsza, byś się lękał. Żywa jest w nakazach i zakazach, skuteczna w obietnicach i groźbach, przenikliwsza w sądach i potępieniach. Lecz skoro prawdzie obietnic i wszechmocy jej dzieł bardziej należy wierzyć niż je roztrząsać, rozważmy, jaka jest wnikliwość jej sądów.

2. Przenikliwsza, rzecze, jest mowa Boża niż wszelki miecz obosieczny ${ }^{51}$. Obosieczny jest miecz, który tnie z obu stron, który gdy się wbije, wdzierając się z jednej i drugiej strony, dwa razy otwiera sobie drogę, przecina on jednak jedynie ciało; miecz Boży natomiast tnie w jednym i drugim miejscu, ponieważ może duszę i ciało zatracić w gehennie ognia ${ }^{52}$. Czy też: w sądach tnie w jednym i drugim miejscu, ponieważ jedno i drugie rozsądza, rozcina i rozróżnia.

Następują słowa, co następuje: $i$ dosięga aż do rozdzielenia duszy $i$ ducha ${ }^{53}$. W każdym człowieku są te trzy: ciało, duch i umysł. Do ciała odnosi się przyjemność, do ducha - myślenie, do umysłu - rozsądzanie. Przyjemność to wąż, myślenie - Ewa, a rozsądzanie - Adam. W przyjemności tkwi pożądliwość nadmiaru, w myśleniu jest zapobiegliwość o to, co niezbędne, w rozsądzaniu wyrok prawdy. Przyjemność pod pozorem niezbędności skłania przezorność do nadmiaru. Przezorność przez współodczuwanie z niższą częścią odwodzi rozum od wyroku prawdy.

Pierwsze rozdzielenie dokonuje się między wężem a Ewą, to znaczy między cielesnością, czyli duszą lub naturą zwierzęcą, a duchem, między przyjemnością a myśleniem, między nadmiarem a niezbędnością. Drugie rozdzielenie dokonuje się między Ewą a Adamem, między myśleniem a zamiarem czy rozsądzaniem, między roztropnością ciała a wyrokiem prawdy. Mowa Boża także niejako rozdziela duszę i ducha, gdy święte słowo nam ukazuje, jaka zachodzi niezgodność między pragnieniami cielesnymi a duchowymi.

Następują słowa: stawów też $i s z p i k u^{54}$, to znaczy: sama mowa Boża sięga nawet aż do rozdzielenia stawów i szpiku. To zaś, co powinniśmy rozumieć przez stawy i szpik, wyjaśnia się, gdy się podstawi: myśli i zamiarów. Stawy to myśli, szpik to zamiary. Pierwszymi od zewnętrznej strony są uczynki, niczym skóra, następnie przyjemność, jakby ciało, potem myśli, jakby kości, potem zamiar, jakby szpik. Jak skóra okrywa ciało, tak uczynki - przyjemność i jak kości podtrzymują ciało, tak myśli karmią pragnienia; a jak szpik tkwi głębiej niż

51 Ibidem.

52 Por. Mt 10,28.

53 Hbr 4,12.

54 Ibidem. 
kości, tak w myślach kryją się zamiary. Myśli nazywane są stawami również dlatego, że poniekąd tak łączą z sobą pragnienia, jak stawy wiążą członki ciała. Staw jest bowiem węzłem, który jako środek łączy krańce. Podobnie i myśli, ponieważ zarówno rodzą się z pragnień, jak i pragnienia rodzą i w pewien sposób te karmiąc, a tamte - rodząc, jedne i drugie z sobą łączą. Wiążą niejako to, co $\mathrm{z}$ nich wynika, $\mathrm{z}$ tym, co je poprzedza, ponieważ one same pochodzą z pragnień, a pragnienia pochodzą z nich.

Skoro więc powiedzieliśmy, że pragnienia rodzą myśli, to każdy, kto poznaje samego siebie, musi dobrze wiedzieć, że na pewno częściej wspominamy w myśli to, ku czemu miłości bardziej doznajemy. Dlatego także Pan mówi w Ewangelii: Gdzie jest skarb twój, tam jest i serce twoje ${ }^{55}$. Tak jak gdyby powiedział: Gdzie jest twoje pragnienie, tam jest twoje serce, to znaczy: gdzie jest twoje uczucie, tam jest i twoja myśl. A z kolei to, że myśli rodzą pragnienia, wyraża Psalmista, mówiąc: $W$ rozmyślaniu moim rozpalit się ogieñ ${ }^{56}$, bo w sercu żarliwiej rozpala się miłość ku temu, o czym myślenie często opanowywało ducha. Trafnie zatem za szpik, który jest bardziej ukryty i zatopiony w ciele, uznaliśmy zamiary, które stanowią jakby szpik naszych myśli, ponieważ w myśli serca kryje się zamiar myśli. Gdy go dokładnie badamy, docieramy jakby do wnętrza kości. Jest zatem dowiedzione, że słusznie nazywa się myśli stawami, a zamiary szpikiem. Pozostaje zbadać, w jaki sposób mowa Boża sięga aż do ich rozdzielenia.

Pierwsze rozdzielenie zachodzi między duszą a duchem, to znaczy między przyjemnościami cielesnymi a duchowymi. Drugie rozdzielenie jest między stawami, to znaczy myślami cielesnymi a duchowymi. Najpierw bowiem rozróżnia się przyjemności, to znaczy, czy duch doznaje dobrego, czy złego pragnienia. To rozróżnienie jest pierwsze dlatego, że każdy może łatwiej osądzić swoje pragnienia. Dalej następuje rozróżnienie myśli, które jest trudniej dostępne i które trudniej się pojmuje. Ponieważ bowiem niekiedy ze złych pragnień rodzą się dobre myśli i przeciwnie, $\mathrm{z}$ dobrych pragnień powstają złe myśli, nie jest łatwo rozróżnić czy zbadać jakość myśli, ponieważ należy je osądzać nie tylko na podstawie poprzedzających je pragnień, z których pochodzą, lecz także na podstawie pragnień $\mathrm{z}$ nich wynikających, które one rodzą.

Jednak, aby dostrzec wyraźniej, w jaki sposób ze złych pragnień rodzą się dobre myśli, a z dobrych pragnień złe, niech zilustruje to przykład. Nie ma nikogo, kto by nie wiedział, że pragnienie rabunku jest złe; jednak niekiedy z pragnienia rabunku rodzi się pragnienie zabijania, a często z pragnienia zabijania rodzi się odraza do morderstwa. Gdy zatem ze złego pragnienia pochodzi myśl

\footnotetext{
55 Mt 6,21.

56 Ps 38(39), 4.
} 
rodząca dobre uczucie, niejako w złym korzeniu dobra gałązka przynosi słodki owoc. Podobnie niekiedy z dobrego pragnienia rodzi się zła myśl, jak wtedy, gdy czasem, czując odrazę do skalania ciała, zaczynamy myśleć o szpetocie pożądliwości cielesnej i wyniku samej myśli rozpalamy się ku niedozwolonej przyjemności, to jakby z czystego źródła zaczynała tryskać woda, lecz ściekając powoli, spływała do ścieku haniebności. Niekiedy jednak myśli pochodzą z dobrych pragnień i rodzą dobre pragnienia lub, podobnie, zrodzone ze złych pragnień przynoszą złe pragnienia.

Ze względu na tę niejasność, skoro ledwo można rozpoznać prawdę, słusznie po rozdzieleniu duszy i ducha, czyli pragnień cielesnych i duchowych, umieszczono rozdzielenie stawów, czyli dobrych i złych myśli, jako bardziej skomplikowane i trudniejsze. Wreszcie, skoro wiadomo, że rozróżnienie zamiarów jest od tego wszystkiego bardziej tajemnicze, nie bez powodu na końcu dodaje się także rozdzielenie szpiku.

A wszystko to przenika w osądzie mowa Boża, bo ten, kto wewnątrz przez mądrość swoją, dokładnie poznając osądza nasze tajemnice, na zewnątrz przez naukę swoją ku pożytkowi nas oświecając, sprawia, że my poznajemy to samo. Ponieważ zatem mowa Boża jest żywa, wierzmy, że On obiecuje to, prawdziwe; ponieważ jest skuteczna, ufajmy, że spełni to, co obiecane; ponieważ jest przenikliwa i nie może się mylić, żałujmy, że Go obraziliśmy i lękajmy się, by Go nie obrazić w przyszłości. On bowiem zna nasze pragnienia i widzi myśli, i pojmuje zamiary.

\section{IV}

1. Następują słowa: Żadne stworzenie nie jest niewidzialne przed obliczem jego ${ }^{57}$. Oko Boże dostrzega to, co odległe, bo wszędzie jest obecne, i to, co najgłębsze, bo jest we wszystkim, i obejmuje to, co subtelne, bo jest przenikliwe, i to, co bardzo duże, bo wszystko jest w Nim. Po tym następują słowa: Wszystkie rzeczy sq obnażone oczom jego ${ }^{58}$, bo w Nim jest wszystko, i odkryte, bo On sam

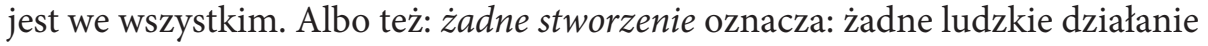
czy myśl, czy zamiar.

2. Jest takie oko, które jest na zewnątrz, a nie ma go wewnątrz - tak jak oko ciała; takie oko, które czemuś służy wewnątrz i czemuś na zewnątrz, jak oko serca; i takie oko, które jest tylko wewnątrz, a nie ma go na zewnątrz, jak oko Boże. Oko ciała widzi tylko to, co znajduje się na zewnątrz ciał, a oko umysłu to, co znajduje się na zewnątrz serc; oko Boże widzi to, co wewnętrzne. Oko

57 Hbr 4,13.

58 Ibidem. 
serca jest wewnątrz w stosunku do oka ciała, a w stosunku do oka Bożego - na zewnątrz. I tak jak oko ciała nie dostrzega tego, co dostrzega oko serca, tak oko serca nie dostrzega tego, co dostrzega oko Boga. Oko Boga dostrzega jednak to, co dostrzega oko serca. A zatem oko ciała dostrzega tylko to, co jest na zewnątrz ciał; oko serca i to, co na zewnątrz, i to, co wewnątrz ciał, lecz tylko to, co na zewnątrz serc; oko zaś Boga dostrzega jednocześnie i to, co na zewnątrz,

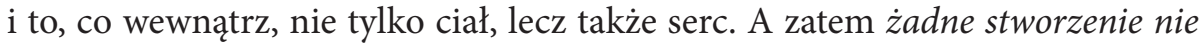
jest niewidzialne przed obliczem jego. Lecz wszystkie rzeczy sq obnażone i odkryte oczom jego ${ }^{59}$.

3. Przed naszymi oczami często kryje się nawet to, co widzialne; to co niewidzialne, jest nam niedostępne. Czyn jest widzialny, zamiar jest niewidzialny. Ale czyny ludzkie, choć w swej naturze są widzialne, na wiele jednak sposobów kryją się przed naszymi oczami, by nie można ich było dostrzec. Zamiaru zaś nie można zobaczyć, nawet gdyby widziano sam czyn. Przed oczami Boga wszystko jest przeto obnażone, ponieważ On widzi wszystkie ludzkie czyny, gdziekolwiek by się dokonywały, ponieważ nie ma ciemności i nie ma cienia śmierci, i nie ma gdzie się ukryć tym, którzy czynią zło; ani okrycie nie osłoni, ani welon nie zasłoni, ani mur nie zamknie, ani mrok nie ukryje nas przed oczami Jego. A zatem wszystko jest obnażone, ponieważ On widzi wszystko, co się dzieje; wszystko odkryte, ponieważ On widzi, z jakim zamiarem jest dokonywane.

1. Następują słowa: do którego nasza mowa ${ }^{60}$, to znaczy: do Boga lub do Jego Słowa; w domyśle albo „jest”, albo „będzie”, albo „powinna” zostać skierowana mowa.

Najpierw jest mowa Boga skierowana do nas, potem - nasza do Boga. Mowa Boża jest do nas kierowana na dwa sposoby: wewnętrznie i zewnętrznie: wewnętrznie przez natchnienie, zewnętrznie - przez głoszenie. Podobnie przez natchnienie na dwa sposoby: przez naturę i przez łaskę. Przez naturę, gdy tchnie w stworzonych poznanie dobra; przez łaskę, kiedy odkupionym wskazuje umiłowanie dobra. $\mathrm{Na}$ dwa również sposoby kieruje się nasza mowa do Niego: albo radzimy się rozumu, albo zdajemy sprawę. Jeśli teraz z wyboru nie chcemy się poradzić rozumu co do postępowania, wtedy z konieczności zdamy sprawę z uczynków, jak jest powiedziane w Apokalipsie: księgi zostały otwar-

59 Ibidem.

60 Por. Hbr 4,13. 
te, a następnie otworzono inna księgę, która jest księga życia, potem osądzono umarlych $z$ tego, co było napisane w owych ksiegach ${ }^{61}$.

2. Księgi to ludzkie serca, księga życia to mądrość Boga. Księgi zostają otwarte, gdy jawne stają się tajemnice serc; księga życia zostaje otwarta, gdy dzięki wewnętrznemu światłu dla każdego w sposób wyraźny jasne staje się wszystko, co należy czynić. A zmarli sądzeni są z tego, co jest w księgach, a nie $\mathrm{z}$ tego, co jest w księdze, ponieważ grzesznicy będą sądzeni ze swoich uczynków. Nasze księgi zostały napisane według księgi Boga, ponieważ nasze serca są stworzone na podobieństwo mądrości Bożej, jak jest powiedziane: Znakiem jest nad nami światłość oblicza Twego, Panie ${ }^{62}$. Ciągle jeszcze powinny być zapisywane nasze księgi według wzoru księgi życia, jak mówi Apostoł: Bądźcie naśladowcami Chrystusa, jak synowie najmilsi ${ }^{63}$. Choć nie zostały jeszcze zapisane, powinno się je przynajmniej poprawiać. Porównajmy przeto nasze księgi z tą księgą, aby je - gdyby zawierały coś innego - poprawić, ażeby ich nie odrzucono, gdyby w owym ostatecznym zestawieniu odkryto, że zawierają coś innego. Tak można rozumieć: do którego, to znaczy Słowa, jest nasza mowa.

3. Albo inaczej: do którego nasza mowa: mówimy do Chrystusa o sobie, aby On sam przemawiał za nami do Ojca, ponieważ jest arcykapłanem, aby składać Bogu ofiary ludu, a jest potężny: potężny co do bóstwa, ponieważ jest Synem Bożym, potężny co do człowieczeństwa, ponieważ przenika niebiosa. Przystąpmy więc $z$ ufnościa do tronu Jego łaski ${ }^{64}$, to znaczy do Niego samego, bo w Nim panuje łaska. Panuje na dwa sposoby, bo nie ma w Nim nieprawości, która by stała na przeszkodzie Jego woli udzielania łaski, ani nie ma w nas nędzy, która by stała na przeszkodzie Jego mocy. Przystąpmy więc z ufnością, gdyż służbą Jego jest modlić się za nas, bo został ustanowiony arcykapłanem, i zasługą Jego to, że zostaje wysłuchany, ponieważ jest sprawiedliwy, a wreszcie ulituje się łaskawie, ponieważ ze względu na nas sam poddany jest słabości ${ }^{65}$.

4. Został ustanowiony - przez Boga, Nie sam się bowiem ustanowił, lecz Bóg Go wywyższyl, gdy powiedział: Tyś jest Synem moim, Jam Ciebie dziś zro$d z i{ }^{66}$. Gdy w czasie chrztu zostało to powiedziane o Chrystusie, wtedy niejako został on wybrany do godności arcykapłana. Gdy zostało to powiedziane na górze $^{67}$, wtedy niejako został ustanowiony arcykapłanem i odziany szatą chwa-

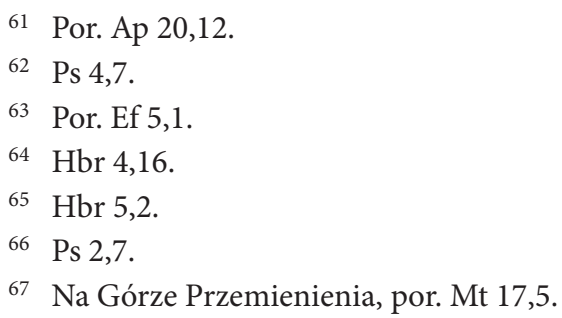


ły. Następnie w trzecim wołaniu, które przybyło do Niego z nieba, mówiąc: I uwielbiłem i jeszcze uwielbię $e^{68}$, został uznany i umocniony w swej godności; tak jak Aaron po ustanowieniu, ponieważ miał pewnych rywali i tych, którzy kwestionowali jego kapłaństwo, został przez Boga uznany i umocniony ${ }^{69}$. Na górze przyjął szatę chwały na znak ustanowienia; w czasie Zmartwychwstania wdział ją, by za nas ofiarować modlitwy Bogu.

1. Albowiem każdy najwyższy kapłan z ludzi wzięty, dla ludzi bywa postanowiony w tym, co do Boga należy, aby składał dary $i$ ofiary za grzechy ${ }^{70}$. Dwojakiego rodzaju powinien być wybór tych, którzy mają przewodzić, taki mianowicie, by najpierw wewnętrznie zostali wybrani do wyjątkowej cnoty, następnie by zewnętrznie przez posłuszeństwo zostali powołani do wyjątkowej godności. Jedni są wybierani wewnętrznie, a zewnętrznie nie, jak dobrzy podwładni, inni są wybierani zewnętrznie, a wewnętrznie nie, jak źli przełożeni; inni zewnętrznie i wewnętrznie, jak dobrzy przełożeni; inni ani zewnętrznie, ani wewnętrznie, jak źli podwładni.

2. Dalej jest, co następuje: dla ludzi bywa postanowiony w tym, co do Boga należy ${ }^{71}$. Powiedziane jest w Ewangelii: Oddajcie Cezarowi to, co należy do Ce$z a r a$, a Bogu to, co należy do Boga ${ }^{72}$. Tak jak Cezar ma swych namiestników dla ludu, którzy mają sprawować to, co należy do Cezara, tak i Bóg ma swoich namiestników dla swojego ludu, którzy mają szukać tego, co należy do Boga. I tak jak namiestnicy Cezara sprawują funkcję legata ludu, by pośredniczyć, a legata Cezara w stosunku do ludu, by rządzić, tak i namiestnicy Boga, to jest przełożeni w Kościele, sprawują urząd legata ludu w stosunku do Boga, by zanosić błagania lub legata Boga w stosunku do ludu, aby wydawać polecenia.

Inna jest bowiem funkcja przełożonego jako legata ludu w stosunku do Boga, a inna jest jako legata Boga w stosunku do ludu. W tej funkcji, w której jest legatem ludu względem Boga, powinien wykazywać pobożność, aby przebłagać Go darami, duchową ofiarą i modlitwami. W tej funkcji, w której jest legatem Boga względem ludu, należy do niego nauczanie tych, którzy nie wiedzą, napominanie tych, którzy grzeszą. O tej funkcji, w której jest legatem ludu

\footnotetext{
$68 \mathrm{~J}$ 12,28.

69 Por. Lb 16, 1-35.

70 Hbr 5,1.

71 Ibidem.

72 Mt 22,21.
} 
względem Boga, powiedziane jest, aby składał Bogu ofiary i dary za grzechy ${ }^{73}$. O tej funkcji, w której jest legatem Boga względem ludu, powiedziane jest, aby potrafit współczuć tym, którzy nie wiedzą i błądza, ponieważ i sam poddany jest stabości $i^{74}$.

3. Są tacy, którzy wiedzą, że znajdują się w stanie słabości, lecz nie uważają, że są słabości poddani, są to ci mianowicie, którzy myślą, że są silni w niektórych swoich działaniach. Ci natomiast, którzy dostrzegają, że we wszystkim są słabi, we własnej ocenie zewsząd doznają słabości.

\section{Bibliografia}

\section{Źródła}

Indiculum omnium scriptorum Magistri Hugonis de sancto Victore que scripsit, ms. Oxford, Merton College 49, w: J. de Ghellinck, La table des matieres de la premiere édition des oeuvres de Hugues de Saint-Victor, Recherches de science religieuse 1 (1910), s. 270-289, 385-396.

Hugon ze św. Wiktora,

— De archa Noe, P. Sicard (éd.), Corpus Christianorum. Continuatio Mediaevalis 176, Turnhout 2001.

- De sacramentis christianae fidei, Patrologiae Cursus Completus, Series Latina, J.P. Migne (ed.), Paris 1854, t. 176, kol. 173A-618B.

- De scripturis et scriptoribus sacris, Patrologiae Cursus Completus, Series Latina, J.P. Migne (ed.), t. 175, kol. 9A-28D.

— De uirtute orandi, w: L'Oeuvre de Hugues de Saint-Victor 1, ed. H. B. Feiss, P. Sicard, Turnhout 1997, s. 126-161.

— Didascalicon de studio legendi. Księga III, 6-19, przekł. M. J. Janecki, Studia Antyczne i Mediewistyczne 15 [50] (2017), s. 167-176.

— Didascalicon, czyli co i jak czytać, przekład z j. łacińskiego P. Pludra-Żuk, wstęp J. Soszyński, Warszawa 2017.

_ Miscellanea, Patrologiae Cursus Completus, Series Latina, J.P. Migne (ed.), Paris 1854, t. 177, kol. 820A-821A.

— O tym, że miłość Boga jest życiem serca, tłum. M. Zembrzuski, https://www.academia.edu/11575522/Hugon_ze_\%C5\%9Bw._Wiktora_-_O_tym_\%C5\%BCe mi\%C5\%82o\%C5\%9B\%C4\%87_Boga_jest_\%C5\%BCyciem_serca [dostęp z dn. 9.09.2019].

_ Sententiae de diuinitate, A.M. Piazzoni (ed.), Studi Medievali, serie 3a, 23 (1982), s. 912-955.

73 Por. Hbr 5,1,

74 Hbr 5,2. 
_ Super Canticum Mariae, w: Loeuvre de Hugues de Saint-Victor 2, E. M. Denner et B. Jollès (ed.), Sous la règle de saint Augustin 7, Turnhout 2000, s. 24-90.

- Super Iierarchiam Dionysii, D. Poirel (ed.), Corpus Christianorum. Continuatio Mediaevalis 228, Turnhout 2015.

Liber ordinis Sancti Victoris Parisiensis, Lucas Jocqué, Ludo Milis (éd.), Corpus Christianorum. Continuatio Mediaevalis 61, Turnhout 1984.

Pismo święte Starego i Nowego Testamentu w przekładzie polskim W.O. Jakuba Wujka S.J. Tekst poprawili i krótkim komentarzem opatrzyli: Stary Testament ks. S. Styś S.J., Nowy Testament ks. W. Lohn S.J., Kraków 1962.

\section{Opracowania}

Bajor W., „Zbawcze piękno” w teorii estetycznej wiktorynów, Roczniki Kulturoznawcze 3 (2012), s. 67-81.

Baron R., Le style de Hugues de Saint-Victor, w: Études sur Hugues de Saint-Victor, Bruges 1963, s. 91-120.

Baron R., Hugues de Saint-Victor, Six opuscules spirituels. Introduction, texte critique, traduction et notes par R. Baron, Paris 1969 (Sources Chrétiennes 155).

Blessing C, Sacramenta in quibus principaliter salus constat. Taufe, Firmung und Eucharistie bei Hugo von St. Viktor, Wien 2017.

Coolman B.T., Hugh of St. Voctor on "Jesus wept": compassion as ideal "humanitatis", Theological Studies 69 (2008), s. 528-556.

Coolman B.T., The Theology of Hugh of St. Victor. An Interpretation, Cambridge 2010.

Feiss H., Mousseau J. (red.), A Companion to the Abbey of Saint Victor in Paris, Leiden-Boston 2017.

Gasparri F., Scriptorium et bureau d'écriture de l'abbaye Saint-Victor de Paris, w: L'Abbaye parisienne de Saint-Victor au Moyen Âge: Communications présentées au XIII Colloque d'Humanisme médiéval de Paris (1986-1988), Jean Longère (red.), Turnhout 1991, s. 119-139.

Ghellinck J. de, La table des matières de la première édition des oeuvres de Hugues de Saint-Victor, Recherches de science religieuse 1 (1910), s. 270-289, 385-396.

Giraud C., Du silence à la parole: Le Latin spirituel d'Hugues de Saint-Victor dans le "De vanitate mundi", Archives d'Histoire Doctrinale et Littéraire du Moyen Âge 77 (2010), s. 7-27.

Goy R., Die Überlieferung der Werke Hugos von St. Viktor. Ein Beitrag zur Kommunikationsgeschichte des Mittelalters, Stuttgart 1976.

Grzywocz K., Rozwój duchowy: rozważania w świetle Hugona od św. Wiktora, w: Aktywizacja w katechezie: szansa czy zagrożenie?, R. Chałupniak, J. Kostorz, W. Spyra (red.), Opole 2002, s. 41-49.

Harkins F.T., Liere F. van (red.), Interpretation of Scripture. Theory. A Selection of Works of Hugh, Andrew, Richard and Godfrey of St Victor, and of Robert of Melun, Turnhout 2012. 
Hauréau B., Les oeuvres de Hugues de Saint-Victor. Essai critique, Paris 1886.

Janecki M. J., Omnia disce. Mistrza Hugona ze Św. Wiktora rady dla studentów, w: Studia Antyczne i Mediewistyczne 15 [50] (2017), s. 159-166.

Janeczek S., Hugon ze św. Wiktora. Myśl filozoficzna, „Powszechna Encyklopedia Filozofii", t. 4, Lublin 2003, s. 620-622.

Korolko M., Sztuka retoryki. Przewodnik encyklopedyczny, Warszawa 1998.

Lausberg H., Retoryka literacka. Podstawy wiedzy o literaturze, przełożył, opracował i wstępem poprzedził A. Gorzkowski, Bydgoszcz 2002.

Longère J. (red.), L'abbaye parisienne de Saint-Victor au Moyen Âge, Communications présentées au XIIIe colloque d’humanisme médiéval de Paris (1986-1986) (Bibliotheca Victorina 1), Turnhout 1991.

Negri L., Lettura stilistica di Ugo di San Vittore: il "De arrha animae", Convivium 24 (1956), s. 129-140.

Németh C., Contemplation and the Cognition of God. Victorine Theological Anthropology and its Decline, (niepublikowana rozprawa doktorska), Central European University, Budapest 2013.

Piazzoni A.M., Il „De unione spiritus et corporis” di Ugo di San Vittore, Studi Medievali 21 (1980), s. 861-888.

Poirel D. (red), Lécole de Saint - Victor de Paris: Influence et rayonnement du Moyen Âge à l'époque moderne (Bibliotheca Victorina 22), Turnhout 2010.

Rorem P., Hugh of Saint Victor, Oxford 2009.

Roszak P., Between Dialectics and Metaphor: Dynamics of Exegetical Practice of Thomas Aquinas, Angelicum 90/3 (2013), s. 507-534.

Roszak P., Credibilidad e identidad. En torno a la Teología de la Fe en Santo Tomás de Aquino, Pamplona 2014.

Sicard P., Hugues de Saint-Victor et son École, Turnhout 1991.

Sicard P., Iter victorinum. La tradition manuscrite des oeuvres de Hugues et de Richard de Saint-Victor. Répertoire complémentaire et études (Biblioteca Victorina 24), Turnhout 2015.

Soszyński J., Wstęp, w: Hugon ze Świętego Wiktora, Didascalicon, czyli co i jak czytać, przekład z języka łacińskiego P. Pludra-Żuk, Warszawa 2017, s. 9-46.

Swieżawski S., Dzieje europejskiej filozofii klasycznej, Warszawa-Wrocław 2000.

Swieżawski S., Homo platonicus w wiekach średnich (Jan Szkot Eriugena, Alcher z Clairvaux, Wilhelm z Conches i Hugon ze św. Wiktora jako przedstawiciele platońskiej koncepcji człowieka), Roczniki Filozoficzne 2/3 (1949-1950), s. 251-297).

Tichy R., Hugon ze św. Wiktora, w: Wszystko to ze zdziwienia. Antologia tekstów filozoficznych z XII wieku, M. Frankowska-Terlecka (red.), Warszawa 2006, s. $269-278$.

Zembrzuski M., „O miłości! Cóż moge o tobie powiedzieć?” Hugona ze św. Wiktora pochwała miłości, Studia Theologica Varsaviensia 1/2017, s. 159-180. 